\title{
Production of Surimi from Whiting (Merlangius Merlangus L. 1758) and Effect of Starch on Surimi Quality during Frozen Storage
}

\author{
Emre Çaglak* \\ Faculty of Fisheries, Recep Tayyip Erdogan University, Turkey
}

Submission: December 15, 2017; Published: March 07, 2018

*Corresponding author: Emre Çaglak, Department of Processing Technology, Faculty of Fisheries, Recep Tayyip Erdogan University, 53100 Rize, Turkey, Email: emre.caglak@erdogan.edu.tr

\begin{abstract}
In this study, pure and starch surimi samples from whiting, which has an important role in the fishing industry, was produced. Analyses of total volatile base nitrogen (TVB-N), thiobarbituric acid (TBA), $\mathrm{pH}$, moisture, sensory attributes, folding, and chewing of surimi samples during frozen storage at $-25 \pm 2{ }^{\circ} \mathrm{C}$ was carried out. TVB-N value of pure surimi was found as $10.68 \mathrm{mg} / 100 \mathrm{~g}$ at the end of frozen storage (12 months), while TVB-N value of starch surimi was $8.75 \mathrm{mg} / 100 \mathrm{~g}$. TBA value of pure surimi $(2.22 \mathrm{mg} \mathrm{MA} / \mathrm{kg})$ was determined higher than starch surimi $(1.93 \mathrm{mg} \mathrm{MA} / \mathrm{kg})$ at the end of storage. TVB-N and TBA values during the storage were within very good quality limit value specified for fish. Starch demonstrated a positive effect on moisture in terms of surimi quality, and moisture values of pure and starch surimi were found as $77.93 \%$ and $74.08 \%$, respectively. $\mathrm{pH}$ values in both pure and starch surimi groups did not show important change, and pH values were determined on average of 7 levels. On sensory evaluation, it was concluded that starch group had a better effect on taste than pure group. As a result of elasticity analyses (chewing and folding), significantly positive effect on surimi quality of starch was observed. However, elasticity results of both groups decreased below under quality limit value at the end of 6 months. According to obtained results, it was determined that whiting is a suitable resource for production of surimi, and starch provides important advantages to especially the gel and sensory quality of the surimi. The result is that the product is economical, it can be stored frozen for a long time, and it is possible to give continuous product to the market and it will contribute to human nutrition and it will bring great benefits to the economy of the country. This surimi product may contribute to human consumption and country's economy, thanks to being economical, storing long time in frozen storage, and enabling continuous product supply to the market of obtained product.
\end{abstract}

Keywords: Surimi; Whiting; Merlangius merlangus; Starch; Frozen storage

Abbreviations: TVB-N: Total Volatile Base Nitrogen; TBA: Thiobarbituric Acid

\section{Introduction}

Preserving foods was as much important as finding them in early ages of humanity. Great improvements were observed in the preservation of food as a result of the developing technology and research. Nowadays, healthy nutrition and diet products are coming to the front line in our lives. Seafood products, with their general structure, are classified in valuable foods category with low protein/amino-acid amount, fat/fatty acid values, and mineral contents.

Surimi is a Japanese term and is defined as mixing the fish meat with sugar, sorbitol, polyphosphate and preservative substances after being shifted from bones and after being washed with water and then filtered [1]. The ability of surimi to form gel and its white look are important parameters for quality. Among the fish species that are suitable for surimi production, there are the white meat fish in the front line [2]. Important developments were determined in surimi production, and in surimi-based products, which were used in Japan for centuries, especially with the use of Alaska Whiting fish in 1960s [3]. In studies conducted on surimi, fish species, water amounts, gel power/structure, color (whiteness), physical-chemical, sensory and microbiological quality factors were investigated.

Most of the seafood product consumption is as fresh consumption. Production of marketable products will contribute greatly to the economics and consumption habits. Surimi production enables the processing of the species that are not made use of or that are made use of in small amounts, the use of high-protein long-life products, and the consumption of products with various looks and tastes with the help of some additives [3]. In this study, Whiting fish was used as raw material for the quality of the surimi. Starch was used to increase the gen force, reduce the moisture, and strengthen 
the binding property by thickening the gel. The changes in quality of the Surimi, which was produced as plain and starchy, were examined during one-year storage period.

\section{Materials and Methods}

35kg. Whiting fish (Merlangius merlangius L. 1758) was used in the study as the material. The heads, tails, entrails, fins and bones were removed and cleaned with clean water, and were minced in mincer. The minced meat was washed with cooled water at a rate of 1:5 (meat/water) and by changing the water each time for 3 times for 10 minutes. Then, it was washed again with water that was cooled with ice that contained salt at a rate of $0.3 \%$ and $1: 5$ (meat/water) for 10 minutes and was filtered. The product that was in the form of minced meat was pressed in bags that had pores for 45 minutes. The $8 \mathrm{~kg}$ raw product that was purified from water was separated into 2 groups of $4 \mathrm{~kg}$ each. $4 \%$ sugar, $0.3 \%$ sodium polyphosphate, $4 \%$ sorbitol were added to the first group; and $4 \%$ sugar $0.3 \%$ sodium polyphosphate, $4 \%$ sorbitol and $8 \%$ wheat starch were added to the second group; and both groups were mixed in mixer for 5 minutes to obtain homogeneity. Surimi was wrapped with aluminum folio and stretch film as $250 \mathrm{gr}$ packages, and was stored at $-23 \pm 1{ }^{\circ} \mathrm{C}$ for analyses. The TVB-N, TBA, Water Amount, PH and Sensory analyses were made with 2-month periods for 1 year, and the Folding and Chewing tests were made each month for 6 months.

TVB-N determination was made by Antonacopoulos with modified Lücke-Geidel Method [4]. Thiobarbituric Acid Determination was made according to Varlık et al. [5]. Then,

Table 1:

\begin{tabular}{|c|c|c|c|c|c|}
\hline Groups & Time (Month) & TVB-N (mg/100g) & TBA (mg MA/kg) & pH & Moisture (\%) \\
\hline \multirow{6}{*}{ Plain Surimi } & 2 & $1.40 \pm 0.00$ & $0.27 \pm 0.02$ & $7.08 \pm 0.02$ & $77.12 \pm 0.40$ \\
\hline & 4 & $6.30 \pm 0.40$ & $0.96 \pm 0.05$ & $7.06 \pm 0.05$ & $77.66 \pm 0.60$ \\
\hline & 6 & $6.65 \pm 0.35$ & $1.01 \pm 0.03$ & $7.08 \pm 0.00$ & $77.12 \pm 0.49$ \\
\hline & 8 & $6.65 \pm 0.35$ & $1.17 \pm 0.03$ & $7.08 \pm 0.01$ & $77.47 \pm 0.82$ \\
\hline & 10 & $8.05 \pm 0.35$ & $1.91 \pm 0.12$ & $7.06 \pm 0.00$ & $76.96 \pm 0.15$ \\
\hline & 12 & $10.68 \pm 0.44$ & $2.22 \pm 0.05$ & $7.04 \pm 0.01$ & $77.33 \pm 0.46$ \\
\hline \multirow{6}{*}{ Starch Surimi } & 2 & $2.80 \pm 0.00$ & $0.35 \pm 0.02$ & $7.07 \pm 0.01$ & $72.49 \pm 0.16$ \\
\hline & 4 & $4.55 \pm 0.20$ & $1.15 \pm 0.13$ & $7.02 \pm 0.01$ & $73.69 \pm 0.39$ \\
\hline & 6 & $5.43 \pm 0.59$ & $1.23 \pm 0.04$ & $7.05 \pm 0.01$ & $72.45 \pm 0.25$ \\
\hline & 8 & $7.00 \pm 0.00$ & $1.31 \pm 0.04$ & $7.05 \pm 0.01$ & $71.22 \pm 0.47$ \\
\hline & 10 & $7.00 \pm 0.00$ & $1.27 \pm 0.10$ & $7.08 \pm 0.01$ & $72.63 \pm 0.47$ \\
\hline & 12 & $8.75 \pm 0.35$ & $1.93 \pm 0.04$ & $7.08 \pm 0.01$ & $74.08 \pm 0.57$ \\
\hline
\end{tabular}

As seen in Table 1, during the storage period, despite the increase observed in TVB-N amounts in both groups, neither of the groups reached $30 \mathrm{mg} / 100 \mathrm{~g}$, which is accepted as quality limit for the samples [9]. In plain and starched surimi groups, the difference in TVB-N amounts between the groups during the 12-month frozen storage period was analyzed with the t-test, and was found to be statistically insignificant $(\mathrm{P}>0.05)$.
$45 \mathrm{ml}$ distilled water was added to $5 \mathrm{gr}$ sample, and mixed with blender to obtain homogeneity, and the $\mathrm{pH}$ measurement was made with Nel 890 Model. The determination of water was made according to Akyıldız [6].

For the Chewing Test (cutting value of teeth), which is one of the Elasticity Analyses, the samples were thawed, and cut in round shapes as $5 \mathrm{~mm}$, and evaluated according to 10-point system (10: extremely hard; 1: no elasticity weak tissue). Folding Test was made according to Lee 5 AA Method. The sample was held with the thumb and pointing finger, and was folded carefully to examine whether there was fractures or not. The test samples were taken in round shapes in $3 \mathrm{~mm}$ thicknesses (5 AA: No fracture after folded to a quarter Very Good - 1 D Fractures when pressed with finger Very Bad) [1]

In Sensory Evaluation, for the taste, color and look tests, the plain and starched surimis were mixed with corn flour as $10 \mathrm{gr}$ portions in the form of a disk without spices in hot sunflower oil for 2-3 minutes, and then were presented to panelists. A 5-Point scoring system was used in scoring (5Very Good; 1-Very Bad) [1,7].

In Statistical Evaluation, the data obtained in the study were analyzed with regression and t-test analyses [8].

\section{Results}

As a result of the physical-chemical analyses, the TVB-N, TBA, $\mathrm{pH}$ and moisture (\%) amounts determined during storage time in plain and starched surimi groups are given in Table 1.
For the purpose of determining the relation between TVB-N amount and storage period, regression analysis was applied, and it was determined that TVB-N increased in a linear manner during the storage period. The regression equation for this relation in the plain surimi group was found as $\mathrm{y}=1.475$ $+0.7339 x$ ( $r=0.91)$; and in the starched surimi group, it was found as $y=2.0533+0.5525 x(r=0.98)$. 
During the storage period, although there was an increase in the TBA amounts, neither of the groups reached 5-8mgMA/ $\mathrm{kg}$, which is accepted as the quality limit for both groups after 1-year frozen preservation period $[5,10]$. In addition, the issue of whether adding starch was influential on TBA amounts was examined with the t-test, and it was determined that starch was not influential on TBA amount $(\mathrm{P}>0.05)$. As a result of regression analyses, it was determined that there is a direct relation between storage period and TBA amounts, and this relation is very strong. The regression equations of the relation in plain surimi group was found as $y=0.016+0.1821 x$ Table 2: $(\mathrm{r}=0.97)$, and in starched surimi group as $\mathrm{y}=0.3726+0.119 \mathrm{x}$ $(\mathrm{r}=0.88)$.

The amount of moisture in both groups showed irregular distribution during the storage period (Table 2). The differences between the starched surimi group and the plain surumi group during the storage periods was found to be significant with the t-test $(\mathrm{P}<0.05)$. This result shows that starch decreases the water loss in 12-month storage period. However, it was determined that there was no relation between storage period and water amount.

\begin{tabular}{|c|c|c|c|c|c|c|}
\hline Groups & Time (Month) & Chewing & Folding & $\begin{array}{c}\text { Color- } \\
\text { Appearance }\end{array}$ & Taste & Time (Month) \\
\hline \multirow{6}{*}{ Plain Surimi } & 1 & $6.75 \pm 0.09$ & $3.75 \pm 0.25$ & $3.65 \pm 0.10$ & $4.35 \pm 0.03$ & 2 \\
\hline & 2 & $6.55 \pm 0.22$ & $3.50 \pm 0.29$ & $4.20 \pm 0.06$ & $4.50 \pm 0.06$ & 4 \\
\hline & 3 & $5.65 \pm 0.05$ & $3.25 \pm 0.25$ & $4.40 \pm 0.00$ & $4.05 \pm 0.03$ & 6 \\
\hline & 4 & $5.80 \pm 0.23$ & $2.50 \pm 0.29$ & $4.38 \pm 0.03$ & $4.08 \pm 0.17$ & 8 \\
\hline & 5 & $5.30 \pm 0.10$ & $2.00 \pm 0.00$ & $4.05 \pm 0.03$ & $3.95 \pm 0.03$ & 10 \\
\hline & 6 & $5.10 \pm 0.06$ & $1.50 \pm 0.29$ & $4.05 \pm 0.15$ & $3.93 \pm 0.08$ & 12 \\
\hline \multirow{6}{*}{ Starch Surimi } & 1 & $7.85 \pm 0.17$ & $4.75 \pm 0.25$ & $3.70 \pm 0.00$ & $4.70 \pm 0.00$ & 2 \\
\hline & 2 & $7.80 \pm 0.08$ & $4.25 \pm 0.25$ & $4.05 \pm 0.03$ & $3.75 \pm 0.09$ & 4 \\
\hline & 3 & $7.05 \pm 0.21$ & $3.75 \pm 0.25$ & $4.40 \pm 0.00$ & $3.95 \pm 0.03$ & 6 \\
\hline & 4 & $7.10 \pm 0.06$ & $3.50 \pm 0.29$ & $4.40 \pm 0.17$ & $4.60 \pm 0.07$ & 8 \\
\hline & 5 & $6.55 \pm 0.17$ & $3.00 \pm 0.00$ & $4.10 \pm 0.00$ & $4.43 \pm 0.16$ & 10 \\
\hline & 6 & $6.10 \pm 0.17$ & $2.25 \pm 0.25$ & $4.13 \pm 0.16$ & $4.55 \pm 0.09$ & 12 \\
\hline
\end{tabular}

One of the factors that affect the gel power is $\mathrm{pH}$, and its showed irregular distributions during the storage period, which was 12 months in both surimi groups (Table 1). It was also determined with the t-test that there were no statistically significant differences between the averages of the two groups $(\mathrm{P}>0.05)$. In addition, it was also determined that there was no relation between storage period and $\mathrm{pH}$ amounts. The $\mathrm{pH}$ values of both groups stayed between 6-8 $\mathrm{pH}$ in terms of forming gel during the storage period [3].

As a result of the regression analyses which were made to determine the relation between chewing values and storage period, it was determined that there was a strong, direct and negative relation between the two surimi groups between chewing values and time (i.e. as the storage period was elongated, the chewing test scores decreased) (Table 2). The regression equations of this relation was found to be $y=7.0433$ $-0.3386 \mathrm{x}(\mathrm{r}=0.95)$ in plain surimi, and as $\mathrm{y}=8.32-0.3557 \mathrm{x}(\mathrm{r}=$ 0.97 ) in starch surimi. The difference between the groups in chewing values was analyzed with the t-test, and it was found to be statistically significant $(\mathrm{P}<0.05)$. The chewing values did not decrease below 5 points (proper light elasticity) in the plain surimi group, and below 6 points (proper elasticity) in the starched surumi group. Regression analysis was made to determine the relation between storage period and folding test scores. The regression equations showing this relation was found to be $y=4.4-0.4714 x(r=0.98)$ in plain surimi, and $\mathrm{y}=5.2333-0.4714 \mathrm{x}(\mathrm{r}=0.99)$ in starch surimi. As the storage period increased, it was determined that the folding test scores decreased, and for this reason, the fold ability was reduced (Table 2). While plain surimi has medium-level and below scores after the 3rd month, starch surimi reached these values after 4 th month. The differences between the folding scores of the groups were determined with the $t$-test, and these differences were found to be statistically significant $(\mathrm{P}<0.05)$. Although the fold ability values in both groups decreased during the storage period, it was observed that this decrease was slower and lower in the starch group.

As a result of the regression analyses that were made to determine the changes in color and look scores of the groups, no relations were detected because of the irregular distribution (Table 2). During the storage period, color and look values did not decrease below the "medium" level, which was determined as 3 points in both groups. The difference between the average color and look values in the groups during the storage period was analyzed with the t-test, and the difference was found to be statistically insignificant $(\mathrm{P}>0.05)$. The taste values in both groups did not decrease below the medium-level quality (3 points) during the study period (Table 2). As a result of the regression analyses made between the taste scores and storage period, a linear relation was determined in the plain surimi group ( $\mathrm{y}=4.53-0.055 \mathrm{x})(\mathrm{r}=-0.91)$, and no relations were detected in the starched surimi group. The obvious 
decrease in terms of taste in plain surimi during the storage period was not detected in starch surimi.

\section{Discussion and Conclusion}

Whiting fish may be the raw material for surimi in which white meat fish are important. In general, surimi yields varies between 22-32 in commercial production [1,11-12]. Hasting \& Tavendale [13] conducted studies and determined that the yield in raw surimi obtained from whiting fish varied between $27 \%-29 \%$ and $34 \%-35 \%$ depending on the additives. Köse et al. [12] reported that the yield was between $25.1 \%-32.5 \%$ in surimi produced from whiting fish. In this study, the yield of surimi was found to be $22.9 \%$. Uzuncanın [14] conducted a postgraduate thesis study with the title of surimi production from anchovy, horse mackerel and whiting fish, and found that surimis had TVB-N values as $4.3 \mathrm{mg} / 100 \mathrm{~g}, 3.5 \mathrm{mg} / 100 \mathrm{~g}$ and $2.8 \mathrm{mg} / 100 \mathrm{~g}$, respectively after 5 -month storage period [12,15-16]. In a study in which surimi-based crab production was made, it was determined that the initial TVB-N amount was $4.5 \mathrm{mg} / 100 \mathrm{~g}$, and did not increase $10 \mathrm{mg} / 100 \mathrm{~g}$ [17]. The TVB-N values after 12 -month storage were $10.68 \mathrm{mg} / 100 \mathrm{~g}$ in plain surimi group, and $8.75 \mathrm{mg} / 100 \mathrm{~g}$ in starch surimi group. After the storage period, both groups remained below $25-30 \mathrm{mg} / 100 \mathrm{~g}$, which is a very good limit for TVB-N $[9,5]$. It was determined in the statistical analyses that starch do not have any effects on the changes in the amount of TVB-N. Köse et al. [16] conducted a study and investigated the quality changes in horse mackerel surimi $-20^{\circ} \mathrm{C}$ in 5 -month storage period. The highest TBA value was found as $0.422 \mathrm{mgMA} / \mathrm{kg}$ in the 5 th month. Kaba [18] determined the TBA value as $2.01 \mathrm{mgMA} / \mathrm{kg}$ in the surimi produced with anchovy after 5-month storage period. Linn et al. [19] reported that washing the minced meat had an important effect on the malonaldehyde amount that occurred as a result of 6-month storage in minced meat of frozen butterfish (Peprilus buri); and claimed that washing removed blood pigments and reduced oxidation. As a result of the frozen storage period, the TBA values were found as $2.22 \mathrm{mgMA} / \mathrm{kg}$ in plain surimi, and as $1.93 \mathrm{mgMA} / \mathrm{kg}$ in starch surimi. Although there were increases in the TBA values during the storage period, it was observed that the values did not reach $3 \mathrm{mgMA} / \mathrm{kg}$, which is a very good level [5]. It was determined as a result of statistical analyses that adding starch did not have and effects on TBA values. Gögüş and Kolsarıcı [20] reported moisture rate in whiting fish as 78.83. Çetin [21] conducted a doctorate study with the title "Processing Anchovy and Tuna Fish" and reported that the moisture values varied between $75.70 \%-63.01 \%$. Sultanbawa and Li-Chan [22] investigated the use of sugar and polyol as cryoprotectant during storage of morina surimi, and after their study, which lasted for 4 months; they reported the moisture values in the three groups as $75.23 \%, 77.85 \%$ and $84.48 \%$. Medina and Garrote [23] conducted a study to determine the washing factors in the surimi production state in frozen Surimi, and found the most proper moisture content as 79\%. Lee conducted a study in 1984 and another one in 1986, and reported that the 80-
$85 \%$ water rate in raw surimi could be reduced to $75-79 \%$ by adding cryoprotectant. Japanese Surimi Union reported that the moisture rate in salt-added surimi and in non-salty surimi could vary between $75 \%-79.5 \%$ [12]. The moisture rates obtained at the end of the study were found to be $76.96 \%$ $77.66 \%$ in plain surimi, and as $71.22 \%-74.08 \%$ in starch surimi. It was determined that adding starch reduced water loss at a significant deal $(\mathrm{P}<0.05)$. Akahane and Shimizu [24] reported the $\mathrm{pH}$ as 7.0 for a good product in kamaboko production; and Lee [1] claimed that the best gel formation was between 6-7 pH. Since surimi-based products are prepared from very different materials and contain very different additives, the $\mathrm{pH}$ may vary according to the product types. It was reported that using phosphate increased $\mathrm{pH}$ in surimi-like products [25]. Sultanbawa \& Li-Chan [22] investigated the effects of using sugar and polyol as cryoprotectant during frozen storage of cod surimi, and found the $\mathrm{pH}$ values as 7.04, 7.13 and 6.91 after the study which lasted for 4 months. Yllmaz et al. [26] reported the $\mathrm{pH}$ value in surimi that was produced from siraz fish as 6.68. During the storage period, small fluctuations were observed in the $\mathrm{pH}$ values during storage period; however, the criteria that were set for quality were not overcome. The $\mathrm{pH}$ was around 7.0 in both groups. No effects were observed on $\mathrm{pH}$ values when starch was added. Kaba [18] evaluated the surimi produced from anchovy in sensory terms and the look, smell, texture and taste did not decline below 4 points at the end of 5-month storage. According to the sensory evaluations, the lowest taste point in plain surimi was 3.93 in $12^{\text {th }}$ month, and the highest taste point was 4.50 in the 4 th month; the lowest color point was 3.65 in the $2^{\text {nd }}$ month, and the highest color point was 4.40 in the $6^{\text {th }}$ month. The lowest taste point in starch surimi was 3.75 in the $4^{\text {th }}$ month, and the highest taste point was 4.70 in the 2nd month; the lowest color point was 3.70 in the 2 nd month; and the highest color point was 4.40 in the 6 th and 8 th months. It is considered that these ups-and-downs observed during the storage period stemmed from the fact that the panelists tested such a product for the first time. In color and look evaluations, it was determined that adding starch did not have any effects, and it was considered that adding starch had positive effects on taste, water amount and elasticity. During the study, the taste, color and look points did not decline below the mediumlevel quality. Köse et al. [12] conducted a study and found the chewing values of the Surimi, which they produced from Whiting fish as plain and cryoprotectant-added as 6 points for the plain one, and 7 points in surimi with additive. In the same study, they determined the folding points as 3 points for plain surimi and 5 points for surimi with additives. The elasticity analyses that were conducted as Chewing and Folding Tests supplement each other. As seen in both tests, the product had a declining process throughout 6-month storage period. At the end of the study period, chewing values were found to be within the light elasticity with 5.1 points in plain surimi, and to be 6.1 in starch surimi, which is within proper elasticity limits. In folding tests, when plain surimi was folded two-fold, it had 2 points in 5 months, which is "easily fractured" (bad); 
and when starch surimi was folded 2 -fold, it had 3 points in the 5 th month, which is "a little fracture" (medium). Since adding starch regulates water amount, it ensured that starch surimi was in a better quality situation in terms of elasticity when compared with plain surimi.

As a result, it was determined that all the values obtained in the study period were in agreement with the results of other studies. It was observed that adding starch had positive contribution to the moisture content and sensory quality of surimi. It is possible to claim in the light of the technological advances that producing different surimis with whiting fish or other fish species is reasonable. Surimi-based products are suitable for nutrition (sufficient in terms of protein and suitable for diets) and may be stored in frozen environments. They may be considered as attractive products because they may be preserved for longer durations, may be presented to the market in a continuous manner, have economic raw material, have high nutritional value, and may have a good structure and look with the proper technology and process steps that will be provided for these purposes.

\section{References}

1. Lee CM (1984) Surimi Process Technology. Food Technology 38(11): 69-80.

2. Kolsarıci N, Ensoy Ü (1996) Surimi Teknolojisi. Gıda Dergisi 21(6): 389-401.

3. Çakli Ş, Duyar HA (2001) Surimi Teknolojisi. Ege Üniversitesi, Su Ürünleri Dergisi, Cilt:18, Sayı: 1-2: 255-269.

4. Ludorf W, Meyer V (1973) Fische und fishcherzeugnisse. Verlag Paul Parey, pp. 297.

5. Varlik C, Uğur M, Gökoğlu N, ve Gün H (1993) Su Ürünlerinde kalite kontrol ilke ve yöntemleri. Gıda Teknolojisi Derneği Yay. No:17. istanbul.

6. Akyıldız R (1984) Yemler Bilgisi Labaratuvar Klavuzu Ikinci Baskı.A.Ü. Zir.Fak. Yay. No:895 Ankara.

7. York RK, Sereda LM (1994) Sensory assessment of quality in fish and seafoods. In: Seafoods: Chemistry, Processing Tecnhnology and Quality. In: Shahidi F \& Botta JR (Eds.), Canada, pp. 232-262.

8. Düzgüneş O, Kesici T, ve Gürbüz F (1993) İstatistik Metodları II, A Ü: Zir Fak Yay 1291. Ders Kitabı. 369. Ankara. 218 s.

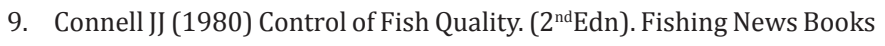
Ltd., Surrey, England, pp. 222.

10. Curran CA, Nicoladies L, Poulter RG, Pars J (1980) Spoilage of fish from Hong Kong at different storage temperatures. Trop Sci 22: 367-382.

11. Lee CM (1986) Surimi Manufacturing and Fabrication of Surimi-based Products. Food Technology. 40 (3): 115-124.

12. Köse S, Uzuncan Y, Özer PN (2000) Mezgit (Merlangius merlangus $L$. 1758)' ten Yarı Manuel Yöntemle Surimi Eldesi ve Donmuş Depolama Esnasındaki Kalite Değişimleri Üzerine Bir Araştırma. Doğu Anadolu
Bölgesi IV. Su Ürünleri Sempozyumu, Haziran, Erzurum, pp. 28-30.

13. Hasting RJ, Tavendale MH (1992) The effect of particul size of mince, and mesh size of dewatering cloth, on the properties of gels of washed whiting (Merlangius merlangus) mince. Int J of Food Sci and Tech 27(6): 643-652.

14. Uzuncan Y (1997) Hamsi, İstavrit ve Mezgitten Surimi Üretimi KTÜ. Fenbilimleri Ensititüsü Balıkçılık Teknolojisi Mühendisliği Anabilim Dalı Yüksek Lisans Tezi. Trabzon, Turkey.

15. Köse S, Uzuncan Y, Ay S (1997) Hamsinin alternatif değerlendirme olanakları, Akdeniz Balıkçılık Kongresi , İzmir, Turkey.

16. Köse S, Uzuncan Y, Boran M (1998) ìstavrit Balığından Surimi Üretim İmkanı ve- $20^{\circ} \mathrm{C}$ ' de 5 Ay Süreyle Muhafazası Sırasında Kalite Üzerinde Meydana Gelen Değişimler. First International Symposium on Fisheries and Ecology Proceedings, Eylül, Trabzon, Turkey pp. 02-04.

17. Yoon IH, Mathces JR, ve Rasco B (1988) Microbiological and Chemical Changes of Surimi - Based Imitation Crab During Storage. J of Food Sci 53(5): $1343-1346$

18. Kaba N (2006) The Determination of Technology \& Storage Period of Surimi Production from Anchovy (Engraulis encrasicholus L., 1758). Turkish Journal of Fsiheries and Aquatic Sciences 6: 29-35.

19. Linn TM, Meyers SP, Golber JS (1996) Storage Stability of Butterfish Mince (Peprilus buri) As Affected by Washing, Antioksidants and Vacuum Packaging. J Aq Food Product 5(2): 19.

20. Göğüs AK ve, Kolsarıcı N (1992) Su Ürünleri Teknolojisi , AÜ Ziraat Fak. Yay:1243, Ankara $261 \mathrm{~s}$.

21. Çetin K (1997) Hamsi ve Orkinos Balıklarının Surimiye iş̧lenmesi Üzerine Teknolojik Araştırmalar. Uludağ Üniversitesi Fen Bilimleri Enstitüsü Gıda Müh. Anabilim Dalı Doktora Tezi. Bursa, Turkey.

22. Sultanbawa Y, Li-Chan, ECY (1998) Cryoprotective effects of sugar and polyol blends in ling cod surimi during frozen storage. Food Research International 31(2): 87-98.

23. Medina JR, Garrote RL (2002) Determining washing contitions during the preparation of frozen surimi from surubi (Pseudoplatystome coruscans) using response surface methodology. Journal of Food Science 67(4): 1455-1461.

24. Akahane Y, Shimizu Y (1989) Studies on water holding capacity of Kamaboko. Bull. Of The Japanese Soc. Of Sci Fisheries 55(10): 18271832.

25. Yapar A, Atay S (2005) Turna Balıği (Esox lucius L., 1758) Etinin Bazı Emülsiyon Özelliklerine Farklı Konsantrasyonlarda Tuz ve Fosfat Kullanımının Etkisi. E.U. Journal of Fisheries \& Aquatic Sciences 22(34): 331-336.

26. Yılmaz H, Aras NM, Haliloğlu Hi, Yılmaz M (2003) Siraz (Capoeta capoeta umbla Heckel, 1843) Balığından Surimi Üretimi Üzerine Bir Araştırma. Atatürk Üniv Ziraat Fak Derg 34(1): 63-67. 
This work is licensed under Creative Commons Attribution 4.0 License

DOI: 10.19080/NFSIJ.2018.05.555672
Your next submission with Juniper Publishers will reach you the below assets

- Quality Editorial service

- Swift Peer Review

- Reprints availability

- E-prints Service

- Manuscript Podcast for convenient understanding

- Global attainment for your research

- Manuscript accessibility in different formats

( Pdf, E-pub, Full Text, Audio)

- Unceasing customer service

Track the below URL for one-step submission https://juniperpublishers.com/online-submission.php 